\title{
KEEFEKTIFAN MODEL TGT DAN JIGSAW DENGAN PENDEKATAN SAINTIFIK PEMBELAJARAN EKONOMI SMA NEGERI DI SLEMAN
}

\author{
FX. Agus Hariyanto, Darmiyati Zuchdi. \\ SMA Kolese De Britto, Universitas Negeri Yogyakarta \\ agushariyanto.debritto@gmail.com, darmiyatiz@yahoo.com
}

\begin{abstract}
Abstrak
Tujuan penelitian ini untuk menguji: (1) keefektifan model Teams Games Tournament (TGT) dan model Jigsaw dengan pendekatan saintifik, (2) membandingkan keefektifan model TGT dan Jigsaw dengan pendekatan saintifik dalam pembelajaran ekonomi SMA Negeri di Kabupaten Sleman. Penelitian ini merupakan penelitian eksperimen semu dengan desain pretest postest non equivalent group design. Populasi penelitian adalah siswa kelas X SMA Negeri di Kabupaten Sleman. Hasil penelitian sebagai berikut: 1) Model TGT dan Jigsaw dengan pendekatan saintifik efektif meningkatkan hasil belajar ranah kognitif, afektif, dan psikomotorik. 2) Ada perbedaan keefektifan signifikan antara model TGT dan Jigsaw. Model Jigsaw mempunyai jumlah indeks gain score ranah kognitif, afektif, dan psikomotoriklebih tinggi dibandingkan TGT. Model TGT mempunyai gain score lebih tinggi dibandingkan dengan Jigsaw untuk hasil belajar ranah kognitif. Model Jigsaw mempunyai gain score lebih tinggi dibandingkan dengan TGT untuk hasil belajar ranah afektif. Model TGT dan Jigsaw menunjukkan gain score yang sama untuk hasil belajar ranah psikomotorik.
\end{abstract}

Kata kunci: team games tournament, jigsaw, pendekatan saintifik

\section{THE EFECTIVENESS OF THE TGT AND JIGSAW MODELS USING THE SCIENTIFIK APPROACHIN ECONOMICS LEARNINGAT STATE SHSS IN SLEMAN}

\author{
FX. Agus Hariyanto, Darmiyati Zuchdi. \\ SMA Kolese De Britto, Yogyakarta State University \\ agushariyanto.debritto@gmail.com, darmiyatiz@yahoo.com
}

\begin{abstract}
This study aims to test: (1) the effectiveness of the Teams Games Tournament(TGT) and Jigsaw modelsusing the scientific approach. (2) tocompare the effectiveness of the TGT and Jigsaw models using the scientific approach in economics learning at state SHSs in Sleman Regency. This was a quasi-experimental study pretest postest non equivalent group design employing the pretest-posttest design. The research population comprised Grade X students of state SHSs in Sleman Regency. The results of the study are as follows. 1) The TGT and the Jigsaw modelswhich are implemented using the scientific approach effectivelyimproves the learning outcome in the cognitive, affective, and psychomotoric domains. 2) There isa significant difference in terms of effectiveness between the two models. Jigsaw model is generates a higher gain score than TGT that was indicated by results of the sum of index gain score cognitive, affective, and psychomotoric aspects learning outcomes. The TGT learning model generates a higher gain score than the Jigsaw for the cognitive domain. The Jigsaw model, however, produces a higher gain score than the $T G T$ for the affective domain. Compared to the Jigsaw model, the TGT learning model shows an equal gain score for the psychomotoric domain.
\end{abstract}

Key word: team games tournament, jigsaw, scientific approach 


\section{Pendahuluan}

Pembelajaran ekonomi bertujuan agar peserta didik memiliki pemahaman terhadap sejumlah konsep ekonomi untuk mengaitkan peristiwa dan masalah ekonomi dengan kehidupan sehari-hari, membentuk sikap bijak, dan rasional sehingga siswa dapat mengambil keputusan yang bertanggung jawab terhadap sejumlah permasalahan ekonomi. Berdasarkan tujuan ini berarti pelaksanaan pembelajaran di sekolah tidak cukup jika hanya dilakukan dengan mengedepankan ranah kognitif peserta didik. Pembelajaran ekonomi memungkinkan mengajarkan siswa untuk mengembangkan ranah afektif dan ranah psikomotorik. Perkembangan peserta didik pada ketiga ranah akan membuat peserta didik berkembang sebagai pribadi yang utuh.

Untuk mencapai tujuan tersebut ada permasalahan yang muncul dengan pemberlakuan kurikulum 2013 oleh pemrintah di sekolahsekolah. Permasalahan dalam penelitian berkenaan dengan model pembelajaran kooperatif sebgai model yang disarankan dalam kurikulum 2013 karena mengaju pada pendekatan siswa aktif.Permasalahan dalam penelitian ini: (1) Apakah model TGT dan Jigsaw efektif dalam pembelajaran ekonomi SMA Negeri di Kabupaten Sleman? (2) Apakah ada perbedaan keefektifan model TGT dan Jigsaw efektif dalam pembelajaran ekonomi SMA Negeri di Kabupaten Sleman?. Rumusan permasalahan ini didapat dari hasil wawancara dan berita pendidikan.

Permasalahan dalam pembelajaran ekonomi menurut Dra. Sri Mardiningsih, M.Pd selaku Pengawas Manajemen Sekolah dan Pengawas Mata Pelajaran Ekonomi di Kabupaten Sleman pada tanggal 20 November 2014 memberikan catatan-catatan yang berkenaan dengan hasil supervisi di sekolah. Catatan yang penting yaitu 1) Masih banyak guru kurang variasi metode dan model dalam pembelajaran, 2) Rencana Pelaksaan Pembelajaran (RPP) beberapa guru tidak sesuai dengan pelaksanaan di lapangan, 3) Beberapa guru masih kurang menggunakan informasi dan teknologi komputer dalam pembelajaran terutama para guru senior. Dari hasil wawancara tersebut bahwa penggunaan model dan metode dalam pembelajaran masih kurang variasi sehingga para guru perlu mencari variasi model dan metode yang menarik. Model kooperatif merupakan salah satu alternatif supaya melibatkan banyak siswa dan mengembangkan kebersamaan siswa.

Menurut Dra. Kristina Sri Sumarni dan guru ekonomi SMA Negeri 1 Gamping yaitu Drs. C. Iriyantoguru ekonomi SMA Negeri 1 Gamping mengemukakan permasalahan pembelajaran ekonomi bahwa 1) Guru-guru ekonomi pernah menggunakan model pembelajaran model Jigsaw dan model TGT tetapi belum menyakini yang dilakukan benar, 2) Guru-guru ekonomi masih kurang memahami implementasi kurikulum 2013. Dari pernyatan tersebut bahwa guruguru ekonomi masih kurang bervariasi dalam pembelajaran cooperatiflearning model TGT dan model Jigsaw secara benar serta masih kurang memahami dalam menjalankan atau implimentasi kurikulum 2013 dalam pembelajaran.

Menurut Kepala sekolah SMP Muhamadiyah 7 dan sebagai guru IPS Ahmad Zainal Fanani, S.Pd., M.A., pemerintah sudah melakukan berbagai upaya untuk meningkatkan kompetensi guru tetapi hasilnya belum maksimal, hal itu terlihat adanya guru yang cenderung bersifat teks book saat mengajar akibatnya kurang kreatif, teknik mengajar yang digunakan monoton (Kedaulatan Rakyat, 19 November 2014.p.10).Menurut Dr. Sugito, M.Pd selaku Ketua Pengurus Besar PGRI bahwa keberhasilan pendidik selain kompetensi dipengaruhi oleh metode pembelajaran yang digunakan guru. Untuk itu supaya siswa mudah menyerap materi pelajaran metode yang digunakan harus dibuat menarik dan disesuaikan dengan perkembangan jaman (Kedaulatan Rakyat, 27 November 2014,p.10).

Peran model pembelajaran yang diadopsi kurikulum 2013 dinilai mempunyai peran yang besar di tahun 2015 karena pada tahun tersebut Indonesia akan banyak mendapatkan angkatan muda produktif sehingga akan menjadi masalah jika tidak dikelola sejak dini karena kebanyakan anak ini masih duduk di bangku sekolah. Menurut Dr. Dadan Rosana Ketua Program Studi IPA FMIPA UNY dalam seminar Nasional di UST Pemantapan Implementasi Kurikulum 2013 untuk menyiapkan Pendidikan dalam pembelajaran saintifik "Kurikulum 2013 mengubah paradigma guru dalam pembelajaran, guru sebagai subjek perubahan. Guru tidak sekedar menyampaikan seperti ceramah tetapi lebih berperan sebagai 
fasilitator, nara sumber, konsultan bagi siswa" (Kedulatan Rakyat, 23 November 2014,p.2).

Pembelajaran ekonomi perlu dirancang secara tepat untuk mencapai tujuan pembelajaran yang telah ditetapkan. Pembelajaran ekonomi idealnya mengupayakan agar peserta didik setelah selesai belajar dapat memanfaatkan hasil-hasil pembelajaran sebagai bekal hidup dan berpartisipasi aktif dalam kehidupan masyarakat. Dalam pembelajaran banyak model yang dapat adopsi untuk mencapai tujuan pembelajaran yang komprehensif ranah kognitif, ranah afektif dan ranah psikomotorik.

Kurikulum 2013 untuk sekolah dasar dan menengah sudah dilaksanakan sejak tahun ajaran 2013/2014. Untuk tahun ajaran 2014/2015 sudah berjalan 2 tahun. Kurikulum 2013 menekankan pada dimensi pedagogik modern dalam pembelajaran, yaitu menggunakan pendekatan ilmiah. Pendekatan ilmiah (scientific approach) dalam pembelajaran sebagaimana dimaksud meliputi mengamati, menanya, mencoba, mengolah, menyajikan, menyimpulkan, dan mencipta untuk semua mata pelajaran (Kemendikbud, 2013,p.5).

Peraturan Menteri Pendidikan dan Kebudayaan nomor 68 tahun 2013 tentang Standar Proses dinyatakan bahwa proses pembelajaran pada kurikulum 2013 menggunakan pembelajaran dengan pendekatan saintifik, terpadu, dan tematik. Pemilihan pendekatan pembelajaran ini dipandang mampu mencapai tujuan pendidikan yaitu keseimbangan pengetahuan, sikap, dan keterampilan dalam diri siswa. Kurikulum 2013 mengamanatkan esensi pendekatan ilmiah dalam pembelajaran. Pendekatan ilmiah diyakini sebagai titian emas perkembangan dan pengembangan sikap, keterampilan, dan pengetahuan peserta didik (Diklat Guru Implementasi kurikulum 2013, 2013,p.1).

Pendekatan saintifik merupakan pendekatan yang berorientasi atau berpusat pada siswa (student centered approach). Pembelajaran berpusat pada siswa (student centered learning) memiliki potensi untuk mendorong siswa lebih aktif, mandiri, sesuai dengan belajarnya masingmasing, sesuai dengan perkembangan usia siswa, iraman yang dipandu agar terus dinamis dan mempunyai kompetensi yang tinggi. Cooperatif Learning merupakan salah satu model dalam pembelajaran yang berorientasi pada siswa.
Model pembelajaran kooperatif seperti Teams Games Tournament (TGT) dan Jigsaw, merupakan model pembelajaran Cooperatif Learnin. Dalam pembelajaran kooperatif didasarkan pada prinsip bahwa siswa harus belajar bersama dan bertanggung jawab atas pembelajarannya sendiri dan pembelajaran temanteman dalam satu kelompok. Tercapainya tujuan dan kesuksesan kelompok bila semua anggota kelompok benar-benar mempelajari materi yang ditugaskan. Pembelajaran kooperatif dengan melibatkan dalam kelompok pembelajaran teman sebaya lebih mudah ditangkap dengan cara bahasa mereka. Model Teams Games Tournament (TGT) dan Jigsaw

Berdasarkan latar belakang masalah tersebut, maka penelitian ini bertujuan untuk: (1) Menguji keefektifan model Teams Games Tournament (TGT) dan Jigsaw dengan pendekatan saintifik dalam pembelajaran ekonomi SMA Negeri di Kabupaten Sleman. (2) Perbedaan keefektifan model Teams Games Tournament (TGT) dan Jigsaw pendekatan saintifik dalam pembelajaran ekonomi SMA Negeri di Kabupaten Sleman.

\section{Metode Penelitian}

Jenis Penelitian

Penelitian ini menggunakan model penelitian Penelitian ini merupakan penelitian eksperimental semu (quasi experimental reseach). Eksperimental semu ini mempunyai kelompok kontrol dan kelompok kontrol ini tidak dapat berfungsi sepenuhnya untuk mengontrol variabel-variabel luar yang mempengaruhi pelaksanaan eksperimen (Sugiyono, 2014, p.77). Desain penelitian ini mengunakan pretestposttest nonequivalent multiple group design (Wiersma,1995, p.143).

Populasi dan Sampel.

Populasi dalam penelitian ini adalah SMA Negeri di Kabupaten Sleman yang berjumlah 17 sekolah. Sampel dalam penelitain ini adalah siswa kelas X SMA Negeri 1 Gamping yang diberikan perlakuan dengan menggunakan model TGT dengan pendekatan saintifik dan siswa kelas X SMA Negeri 1 Prambanan yang diberikan perlakuan dengan menggunakan model Jigsaw dengan pendekatan saintifik 
Waktu dan Tempat Penelitian

Penelitian ini dilakukan pada bulan Februari - Mei 2015. Penelitian dilakukan di dua tempat yaitu di SMA Negeri 1 Gamping beralamat di Tegalyoso, Baturaden, Gamping Sleman dan SMA Negeri 1 Prambanan beralamat di Madubaru, Madurejo, Prambanan, Sleman. Subjek Penelitian

Subjek penelitian dalam ekperimen semu adalah siswa kelas X SMA Negeri 1 Gamping dan siswa kelas X SMANegeri 1 Prambanan.

\section{Prosedur Penelitian}

Berdasarkan model penelitian eksperimental langkah-langkah penelitian yaitu, (1) memilih dan merumuskan masalah; (2) memilih subjek dan instruemn pengukuran; (3) memilih desain penelitian; (4) melaksanaka prosedur penelitian; (5) menganalisis data; dan (6) merumuskan kesimpulan (Emzir, 2013:p.69). Sesuai denganprosedur penelitian eksperimen dengan eksperimental semu untuk mencari keefektifan model TGt dan Jigsaw dengan pebdekatan saintifik dalam pembelajaran ekonomi SMA Negeri di Kabupaten Sleman dalam bagan penelitian sebagai berikut:

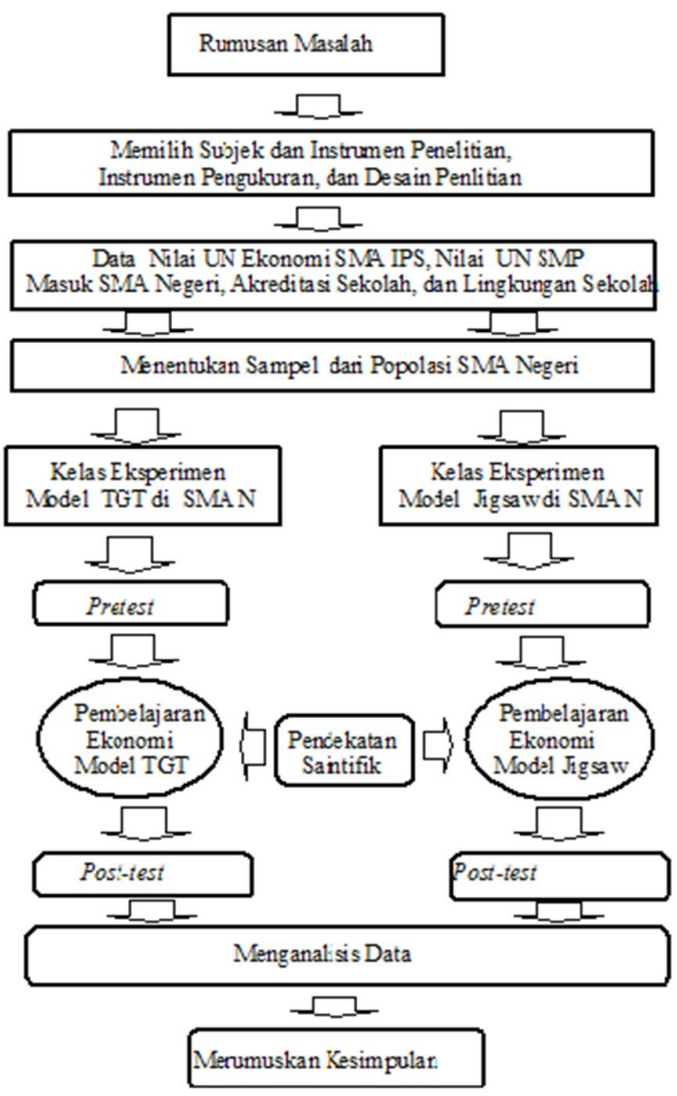

Gambar 1. Prosedur Penelitian Eksperimen
Teknik dan Instrumen Pengumpulan Data

\section{Teknik Pengumpulan Data}

Dalam penelitian ini menggunakan data kuantitatif dengan dokumentasi, tes dan angket. Datadokumentasi untukmendapatkan data nilai UN SMA dan nilai masuk SMA Negeri. Tes tertulis untuk ranah kognitif dan ranah psikomotorik dan angket untuk ranah afektif.

\section{Instrumen Pengumpulan Data}

Tes yang digunakan dalam penelitian ini adalah tes tertulis untuk mendapatkan data hasil belajar ranah kognitif dan hasil belajar ranah psikomotorik. Pada tes tertulis ranah kognitif ini berbentuk pilihan ganda berjumlah 30 soal pilihan ganda. Pemberian skor benar adalah 1 dan skor salah adalah 0 sehingga skor tertinggi 30 dan terendah 0 . Sebelum instrumen ranah kognitif ekonomi

Instrumen kemampuan ranah psikomotorik digunakan tes keterampilan. Bentuk tes berbentuk mengisi bangko atau format yang telah disediakan. Instrumen keterampilan ini berjumlah 3 yaitu keterampilan membuat bukti pembayaran dan keterampilan membuat alat pembayaran nontunai. Soal 1 membuat kuitansi ada 6 bagian yang harus diisi, soal 2 membuat alat pembayaran nontunai berupa cek ada 6 bagian yang harus diisi, dan soal 3 membuat alat pembayaratn nontunai bilyet giro ada 8 bagian yang harus diisi. Masing-masing skor 2 (diisi dengan benar tanpa coretan), skor 1 (diisi benar tetapi ada coretan), dan skor 0 (diisi salah atau tidak diisi). Skor tertinggi 40 dan skor terendah 0 . Untuk mendapatkan nilai dikonversikan dalam rentang 100 .

Instrumen nontes berbentuk angket. Jumlah instrumen ranah afektifkerjasama ada 16 item. Lembar angket terdiri dari beberapa pernyataan dan responden menjawab dengan cara memberi tanda (v) pada pilihan yang telah disediakan. Pilihan berupa pernyataan SLL (Selalu), SS (Sangat Sering), S (Sering), KK (KadangKadang), dan TP (Tidak Pernah). Pengukuran ranah afektif kerjasama di dalam penelitian ini menggunakan skala Likert, skor tertinggi adalah 5 dan skor terendah 1 . Untuk pernyataan positif digunakan skor sebagai berikut: SLL (skor5), SS (4), S (3), KK (2) dan TP (1). Pemberian skor untuk pernyataan negatif skor sebagai berikut: 
SLL (1), SS (2), S (3), KK (4), dan TP (5). Skor tertinggi 80 dan skor terendah 16 . Untuk penilaian dikonversikan dalam rentang 100.

\section{Teknik Analisis Data}

Untuk menguji keefektifan satu model pembelajaran dengan pendekatan saintifik digunakan teknik analisis uji t paried samples test. Untuk membandingkan keefektifan model
Teams Games Tournament (TGT) dengan model Jigsaw digunakan teknik analisis uji multivariat gain score dan gain scoreindependent sample $t$ test.

\section{Hasil Penelitian dan Pembahasan}

Keefektifan model TGT dengan pendekatan saintifik.

Tabel 1. Analisis Hasil Belajar Ekonomi Kelas TGT di SMA Negeri 1 Gamping dengan uji t paried sample test.

\begin{tabular}{clccccc}
\hline No & $\begin{array}{c}\text { Hasil Belajar } \\
\text { Ranah }\end{array}$ & $\begin{array}{c}\text { Rerata } \\
\text { Pretest }\end{array}$ & $\begin{array}{c}\text { Rerata } \\
\text { Posttest }\end{array}$ & Peningkatan & t hitung & Sig \\
\hline 1 & Kognitif & 59,75 & 84,50 & 25,69 & 13,09 & 0,00 \\
2 & Afektif & 79.56 & 84,25 & 4,69 & 6,862 & 0,00 \\
3 & Psikomotorik & 76,19 & 84,88 & 8,69 & 7,082 & 0,00 \\
\hline
\end{tabular}

Hopotesis Penelitian:

Ho : $\mathrm{t}_{\text {hitung }} \leq \mathrm{t}_{\text {tabel }}(2,04)$ dan $\mathrm{p} \geq \alpha=0,05$ Model TGT dengan pendekatan saintifik pada pembelajaran ekonomi tidak meningkatkan kemampuan siswa yang berarti tidak efektif.

Ha $: \mathrm{t}_{\text {hitung }}>\mathrm{t}_{\text {tabel }}(2,04)$ dan $\mathrm{p}<\alpha=0,05$ Model TGT dengan pendekatan saintifik pada pembelajaran ekonomi meningkatkan kemampuan siswa yang berarti efektif.

Hasil analisis menggunakan uji t Paired Samples Test pada pretest dan posttest ranah kognitif mengalami peningkatan 25,688 dan diperoleh nilai $t_{\text {hitung }}$ hasil belajar ranah kognitif 13,092 melebihi nilai $t$ tabel 2,04 dengan taraf signifikansi $0,000<\operatorname{sig} \alpha 0,05$. Adanya peningkatan rerata sebesar 25,688 atau $43,68 \%$ , nilai $\mathrm{t}_{\text {hitung }}=\mathrm{t}_{\text {tabel }}$ dengan signifikansi 0,0000 maka dapat disimpulkan pembelajaran ekonomi dengan model TGT dengan pendekatan saintifik efektif untuk aspek ranah kognitif. Pretest dan posttest ranah afektif mengalami peningkatan 4,688 dan nilai $\mathrm{t}_{\text {hitung }}$ hasil belajar ranah afektif 6,862 , dengan taraf signifikansi $0,000<\operatorname{sig} \alpha 0,05$. Adanya peningkatan rerata sebesar 4,688 atau $5,89 \%$, nilai $\mathrm{t}_{\text {hitung melebihi }} \mathrm{t}_{\text {tabel }}$ dengan signifikansi 0,0000 maka dapat disimpulkan pembelajaran ekonomi dengan model TGT dengan pendekatan saintifik efektif untuk aspek ranah afektif. Pretest dan posttest ranah psikomotorik mengalami peningkatan 8,688 dan diperoleh nilai $\mathrm{t}_{\text {hitung }}$ hasil belajar ranah psikomotorik 7,082 melebihi nilai t tabel 2,04 dengan taraf signifikansi $0,000<\mathrm{sig}$ $\alpha 0,05$. Adanya peningkatan rerata sebesar 8,688 atau $11,40 \%$, nilai $\mathrm{t}_{\text {hitung }}$ melebihi $\mathrm{t}_{\text {tabel }}$ dengan signifikansi 0,0000 maka dapat disimpulkan pembelajaran ekonomi dengan model TGT dengan pendekatan saintifik efektif untuk ranah psikomotorik.

Pembelajaran ekonomi dengan model TGT dengan pendekatan saintifik efektif untuk aspek ranah kognitif, ranah afektif, dan ranah psikomotorik di SMA Negeri 1 Gamping, penelitian ini mendukung penelitian sebelumnya yaitu: (1) Ke, Fengfeng \& Grabowski, Barbara (2007) menjelaskan bermain games lebih efektif meningkatkan hasil pembelajaran matematika dan meningkatkan sikap siswa dari pada dengan cara latihan-latihan, (2) Saptono, (2011) menyimpulkan bahwa melalui model pembelajaran kooperatif tipe Teams Games Tournament mampu meningkatkan prestasi belajar siswa dalam kompetensi dasar kebijakan pemerintah bidang ekonomi pada siswa kelas X3 di SMA Negeri 2 Yogyakarta, (3) Hasil penelitian Velllo, Arsaythamby \& Chairhany, Sitie.(2013) tentang "Fostering students attitudes and achievemengt in probalility using teams games tournament" menyimpulkan hasil penelitiannya bahwa ada perbedaan yang signifikan dalam memperbaiki sikap, meningkatkan prestasi 
dan membuat siswa kreatif dan aktif dalam pembelajaran kooperatif TGT, (4) Gonzales, Jennings, \& Manriquez, (2014) menjelaskan bahwa pembelajaran Teams Games Tournament efektif meningkatkan nilai yang lebih tinggi dan meningkatkan kepuasan siswa daripada pembelajaran yang pembelajaran individu yang tradisional

Pembelajaran efektif menurut Sani tidak terlepas dari peran guru yang efektif, kondisi pembelajaran yang efektif, ketertlibatan peserta didik, dan sumber belajar/ lingkungan belajar yang mendukung. Di SMA Negeri 1 Gamping peran Guru ekonomi sangat penting, dengan pengalaman yang cukup punya peranan yang tinggi. Kesiapan guru mengajar baik secara mental maupun secara adminitrasi. Pengalaman guru mengajar sudah 31 tahun dengan golongan IVa bisa dikatakan guru senior sehingga punya pengalaman untuk mengelola sekolah. Rencana untuk pembelajaran sudah disiapkan seperti Rencana Pelaksanaan Pembelajaran tentang sistem pembayaran dan alat pembayaran untuk kelas X, media yang di gunakan yaitu PowerPoint, metode yang digunakan adalah model Teams Games Tournament (TGT). Dalam pelaksanaan pembelajaran guru sudah sesuai dengan RPP yang disiapkan dan mengaktifkan siswa terlibat dalam pembelajaran. Guru tidak hanya mengajar saja tetapi memberikan nilai-nilai kehidupan seperti pentingya ilmu ekonomi serta kerjasama.

Pendapat Kennet (Rusman,2013,p.326) bahwa implementasi pembelajaran efektif meliputi tujuh langkah yang sudah dijalankan oleh guru. Tujuh langkah tersebut yaitu: (1) perencanaan, (2) perumusan tujuan/ kompetensi, (3) pemaparan perencanaan kepada siswa, (4) proses pembelajaran dengan berbagai strategi, (5) evaluasi, (6) menutup proses, (7) tindak lanjut. Kondisi pembelajaran, keadaan siswa sangat mendukung untuk pembelajaran ekonomi. Pengalaman mengajar yang dimiliki guru, relasi guru dengan siswa-siswi yang dekat mempermudah dalam pengelola kelas sehingga kelas konduksif. Dengan kelas yang konduksif mempermudah dalam proses pembelajaran. Keterlibatan siswa yang aktif mendukung tercapainya tujuan pembelajaran. Di SMA Negeri Gamping dalam pembelajaran model TGT dengan pendekatan saintifik melibatkan peran aktif siswa. Prinsip belajar kooperatif melibatkan peran aktif siswa.
Dalam model TGT Slavin (Rusman, 2013,p.22) mengemukakan pendapat bahwa pembelajaran kooperatif model TGT ada 5 tahap yaitu: (1) penyajian kelas, (2) belajar dalam kelompok, (3) permainan, (4) pertandingan, (5) penghargaan. Kelima tahap tersebut dalam penelitian ini sudah dijalankan, hal ini terihat dari pengamatan. Guru menyajikan film tentang uang, berikutnya siswa belajar dalam kelompok yang telah dibentuk secara heterogen baik jenis kelamin, dan tingkat pengetahuan. Di dalam kelompok diberi materi atau soal yang untuk dikerjakan, setelah itu dipresentasikan.

Tahap ketiga dan keempat siswa bermain game dan turnamen. Pada tahap permainan dan turnamen yang pertama: setiap kelompok diberi lembar kerja siswa yang berupa teka-teki silang. Lembar kerja tersebut dikerjakan bersama-sama. Pada tahap permainan dan turnamen yang kedua: setiap kelompok diberi lembar kerja yang tempelkan di papan tulis, lembar pertanyaan disediakan di bawah papan tulis. Ada 12 pertanyaan sehingga setiap orang mendapatkan soal 2 pertanyaan secara bergiliran dengan durasi waktu 15 detik. Pada tahap permainan dan turnamen ketiga: pertanyaan rebutan, siswa yang terlebih dulu memberikan isyarat dengan tunjuk jari untuk menjawab. Apabila jawaban benar mendapai nilai 10 tetapi kalau salah -10 . Setelah selesai maka nilai pada game dan turnamen 1,2 , dan 3 dijumlahkan untuk menentukan kelompok yang terbaik.

Kelompok yang nilainya paling banyak mendapatkan penghargaan berupa barang yaitu permen. Seluruh aktivitas TGT sudah dilalui dan menurut pendapat para siswa semuanya merasa senang dan berminat. Pendapat siswa melalui lembar refleksi bahwa dengan model TGT siswa dapat lebih aktif, lebih senang, lebih berminat sehingga medapatkan pengetahuan yang mudah melalui pembelajaran dengan model TGT.

Sumber belajar seperti handout atau materi sudah ada karena siswa mempunyai buku pegangan. Selain itu materi-materi mudah didapatkan melalui internet sehingga mudah diakses oleh para siswa karena sebagian besar siswa memiliki HP yang bisa untuk akses internet. Fasilitas internet difasilitasi oleh pihak sekolah sehingga mendukung internet sebagai sumber belajar. Dukungan sekolah lainnya dalam proses pembelajaran dengan ruang untuk pembelajaran 
mendukung seperti ruangan yang cukup luas dengan ukuran $9 \mathrm{~m}$ x $8 \mathrm{~m}$, kelas dilengkapi LCD Projektor, peraturan yang diterapkan berjalan serta suasana kelas atau sekolah kondusif untuk pembelajaran karena jauh dari jalan raya.

Pendekatan saintifik dalam penelitian ini tampak pada siswa mengamati film tentang uang mengamati PowerPoint yang disajikan oleh guru, serta media internet sebagai sumeber belajar Setelah adanya film, PowerPoint dari guru, siswa bertanya kepada guru maupun kepada siswa lain yang tergabung dalam kelompok yang heterogen. Tahapmengumpulkan informasi, mengasosiasi, berpendapat terlihat dalam kerja kelompok. Guru memberikan soal atau pertanyaan yang bisa memotivasi siswa berdiskusi. Tahap mengomunikasikan bahwa hasil dari diskusi dipresentasikan di depan kelas. Pendekatan saintifik berakitan dengan metode pembelajaran kooperatif model TGT sehingga siswa mengalami pembelajaran.

Keefektifan model TGT dengan pendekatan saintifik.

Tabel 2. Analisi Hasil Belajar Ekonomi Kelas Jigsaw di SMA Negeri 1 Prambanan dengan uji t paried sample test.

\begin{tabular}{ccccccc}
\hline No & $\begin{array}{c}\text { Hasil Belajar } \\
\text { Ranah }\end{array}$ & $\begin{array}{c}\text { Rerata } \\
\text { Pretest }\end{array}$ & $\begin{array}{c}\text { Rerata } \\
\text { Posttest }\end{array}$ & Peningkatan & thitung & Sig \\
\hline 1 & Kognitif & 67,17 & 82,21 & 15,04 & 8,866 & 0,00 \\
2 & Afektif & 78,34 & 86,86 & 8,52 & 8,717 & 0,00 \\
3 & Psikomotorik & 77,00 & 87,45 & 10,45 & 9,757 & 0,00 \\
\hline
\end{tabular}

Hipotesis Penelitian:

Ho: $\mathrm{t}_{\text {hitung }} \leq \mathrm{t}_{\text {tabel }}(2,04)$ dan $\mathrm{p} \geq \alpha=0,05$ Model Jigsaw dengan pendekatan saintifik pada pembelajaran ekonomi tidak meningkatkan kemampuan siswa yang berarti tidak efektif.

Ha: $\mathrm{t}_{\text {hitung }}>\mathrm{t}_{\text {tabel }}(2,04)$ dan $\mathrm{p}<\alpha=0,05$ Model Jigsaw dengan pendekatan saintifik pada pembelajaran ekonomi meningkatkan kemampuan siswa yang berarti efektif.

Hasil analisis menggunakan uji t Paired Samples Test pada pretest dan posttest ranah kognitif meningkat 15,034 dan diperoleh nilai $\mathrm{t}_{\text {hitung }}$ hasil belajar ranah kognitif 8,866 melebihi nilai $\mathrm{t}_{\text {tabel }} 2,04$ dengan taraf signifikansi 0,000 $<\operatorname{sig} \alpha 0,05$. Adanya peningkatan rerata sebesar 15,034 atau $22,38 \%$, nilai $t_{\text {hitung }}$ melebihi $t$ tabel dengan signifikansi 0,0000 maka dapat disimpulkan pembelajaran ekonomi dengan model Jigsaw dengan pendekatan saintifik efektif untuk aspek kognitif. Pretest dan posttest ranah afektif meningkat 8,17 dan diperoleh nilai $t_{\text {hitung }}$ hasil belajar ranah afektif 8,717 , melebihi nilai $\mathrm{t}_{\text {tabel }} 2,04$ dengan taraf signifikansi $0,000<\mathrm{sig}$ $\alpha 0,05$. Adanya peningkatan rerata sebesar 8,17 atau $10,87 \%$, nilai $\mathrm{t}_{\text {hitung }}$ melebihi $\mathrm{t}_{\text {tabel }}$ dengan signifikansi 0,0000 maka dapat disimpulkan pembelajaran ekonomi dengan model Jigsaw dengan pendekatan saintifik efektif untuk ranah afektif. Pretest dan posttest ranah psikomotorik meningkat 10,448 dan diperoleh dan nilai $t_{\text {hitung }}$ hasil belajar ranah psikomotorik 9,757 melebihi nilai $\mathrm{t}_{\text {tabel }} 2,04$ dengan taraf signifikansi 0,000 $<\operatorname{sig} \alpha 0,05$. Adanya peningkatan rerata sebesar 10,448 atau $13,57 \%$, nilai $\mathrm{t}_{\text {hitung }}$ melebihi $\mathrm{t}$ tabel dengan signifikansi 0,0000 maka dapat disimpulkan pembelajaran ekonomi dengan model Jigsaw dengan pendekatan saintifik efektif untuk ranah psikomotorik.

Pembelajaran ekonomi dengan model Jigsaw dengan pendekatan saintifik efektif untuk ranah kognitif, ranah afektif, dan ranah psikomotorik di SMA Negeri 1 Prambanan, penelitian ini mendukung penelitian sebelumnya yaitu: (1) Mengduo, Qiao \& Xiaoling, Jin (2010) menjelaskan bahwa teknik Jigsaw adalah cara yang efektif untuk meningkatkan partisipasi dan antusiasme siswa dalam pelajaran bahasa untuk mencapai hasil belajar yang lebih baik, (2) Kartikawati (2012) menyimpulkan bahwa melalui model pembelajaran kooperatif tipe Jigsaw dapat meningkatkan hasil pembelajaran ranah kognitif rerata ranah kognitif dan ketuntasan belajar naik. (3) Adams (2013) menjelaskan bahwa teknik Jigsaw sangat bermanfaat. Siswa mengalami perkembangan dan berminat dalam kerjasama dengan teman-temannya, sebagian besar siswa aktif selama dan setelah pembelajaran. (4) Akan 
tetapi penelitian ini tidak sependapat dengan penelitian Sengul, Sare \& Katranci, Yasemin (2014) menjelaskan bahwa teknik jigsaw tidak memiliki pengaruh pada peningkatan sikap siswa terhadap matematika tetapi ada perbedaan signifikan berdasarkan skor yang diperoleh dari posttest.

Pembelajaran efektif menurut Sani (2013.p.43) tidak terlepas dari peran guru yang efektif, kondisi pembelajaran yang efektif, keterlibatan peserta didik, dan sumber belajar/ lingkungan belajar yang mendukung. Di SMA Negeri 1 Prambanan peran Guru ekonomi sangat penting dengan pengalaman yang cukup punya peranan yang tinggi. Kesiapan guru mengajar baik secara mental maupun secara administrasi. Pengalaman guru mengajar sudah 31 tahun dengan golongan IVa bisa dikategorikan guru senior sehingga punya pengalaman untuk mengelola sekolah. Rencana untuk pembelajaran sudah disiapkan seperti Rencana Pelaksanaan Pembelajaran tentang sistem pembayaran dan alat pembayaran untuk kelas $\mathrm{X}$, media yang di gunakan yaitu PowerPoint, metode yang digunakan adalah model Jigsaw. Dalam pelaksanaan pembelajaran guru sudah sesuai dengan RPP yang disiapkan dan mengaktifkan siswa terlibat dalam pembelajaran. Guru tidak hanya mengajar saja tetapi memberikan nilainilai kehidupan seperti pentingya ilmu ekonomi serta kerjasama.

Melihat dari pendapat Kennet (Rusman,2013,p.326) bahwa implementasi pembelajaran efektif meliputi tujuh langkah yang sudah dijalankan oleh guru. Tujuh langkah teersebut yaitu: (1) perencanaan, (2) perumusan tujuan/ kompetensi, (3) pemaparan perencanaan kepada siswa, (4) proses pembelajaran dengan berbagai strategi,(5) evaluasi, 6) menutup proses, (7) tindak lanjut.

Kondisi pembelajaran, keadaan siswa sangat mendukung untuk pembelajaran ekonomi. Pengalaman mengajar yang dimiliki guru, relasi guru dengan siswa-siswi yang dekat mempermudah dalam pengelolaan kelas sehingga kelas konduksif. Dengan kelas yang konduksif mempermudah dalam proses pembelajaran. Keterlibatan siswa yang aktif mendukung tercapainya tujuan pembelajaran. Di SMA Negeri 1 Prambanan dalam pembelajaran model Jigsaw dengan pendekatan saintifik melibatkan peran aktif siswa. Prinsip belajar kooperatif melibatkan peran aktif siswa.

Dalam model Jigsaw, Slavin (Rusman, 2013,p.22) mengemukakan pendapat bahwa pembelajaran kooperatif model Jigsaw ada 5 tahap yaitu: (1) membaca, (2) diskusi kelompok ahli, (3) laporan kelompok, (4) kuis, (5) perhitungan skor kelompok dan penghargaan. Kelima tahap tersebut dalam penelitian ini sudah dijalankan, hal ini terihat dari bukti pengamatan. Guru menyajikan film tentang uang, berikutnya siswa berkelompok dengan kelompok yang telah dibentuk secara heterogen baik jenis kelamin, dan tingkat pengetahuan. Di dalam kelompok ada 4 sampai 5 orang. Berikutnya siswa menentukan sendiri berdasarkan kesepakatan kelopompok topik atau tema yang akan dibaca untuk dipelajari masuk tahap pertama yaitu membaca.

Pada tahap kedua siswa yang mendapat tema yang sama berkelompok untuk diskusi sebagai tahap kelompok ahli. Ada 5 topik atau tema yang ditentukan oleh guru dalam topik ini. Pada tahap ketiga laporan kelompok yaitu para ahli tersebut menyampaikan laporan kepada kelompok yang materi berbeda dalam kelompok semula.

Sebelum tahap keempat diadakan kuis, dalam penelitian ini diberi tambahan diskusi untuk mengembangkan dan memperdalam materi. Soal diskusi diberikan ke semua kelompok untuk di bahas. Setelah dibahas kemudian dilaporkan melalui presentasi tiap kelompok. Setelah diskusi dan presentasi kelompok guru memberikan penguatan dan peneguhan kembali melalui penjelasan dan tanya dengan media PowerPoint. Tahap keempat yaitu kuis atau tagihan. Setelah tagihan dilakukaan perhitungan dan penghargaan. Seluruh aktivitas model jigsaw sudah dilalui dan menurut pendapat siswa semuanya senang dan berminat. Pendapat ini didapatkan dari refleksi siswa.Pendapat dari refleksi siswa bahwa dengan model jigsaw siswa dapat lebih aktif, lebih senang, lebih berminat sehingga medapatkan pengetahuan yang mudah melalui pembelajaran dengan model Jigsaw.

Sumber belajar seperti handout atau materi sudah ada karena siswa mempunyai buku pegangan, materi-materi mudah didapatkan melalui internet sehingga mudah diakses oleh para siswa karena sebagian besar siswa 
memiliki HP yang bisa untuk akses internet. Fasilitas internet difasilitasi oleh pihak sekolah sehingga mendukung internet sebagai sumber belajar. Dukungan sekolah lainnya dalam proses pembelajaran dengan ruang untuk pembelajaran mendukung seperti ruangan yang cukup luas dengan ukuran $9 \mathrm{~m} \times 8 \mathrm{~m}$, kelas dilengkapi LCD projector, suasana kelas atau sekolah kondusif pembelajaran karena jauh dari jalan raya.

Pendekatan saintifik dalam penelitian ini tampak pada siswa mengamati film tentang uang, membaca buku, mengamati PowerPoint yang disajikan oleh guru, serta media internet sebagai sumber belajar. Setelah film dan PowerPoint ditayangkan guru, siswa bertanya kepada guru maupun kepada siswa lain yang tergabung dalam kelompok yang heterogen. Tahap mengumpulkan informasi, mengasosiasi, berpendapat terlihat dalam kerja kelompok. Guru memberikan soal atau pertanyaan yang bisa memotivasi siswa berdiskusi. Tahap mengomunikasikan hasil diskusi dipresentasikan di depan kelas. Pendekatan saintifik berkaitan dengan metode pembelajaran kooperatif model jigsaw sehingga siswa mengalami pembelajaran.

Komparasi keefektifan model TGT dan Model Jigsaw dengan pendekatan saintifik.

Uji multivariat dalam analisis ini untuk mengetahui ada tidaknya perbedaan dua model TGT dan Jigsaw dengan 3 aspek yaitu aspek kognitif, aspek afektif, dan aspek psikomotorik.
Tabel 3. Hasil Uji Hotelling's antara Model TGT dan Jjigsaw Gain score setelah Perlakuan.

\begin{tabular}{ccccc}
\hline Nilai & F & $\begin{array}{c}\text { Derajat } \\
\text { Kebe- } \\
\text { basan }\end{array}$ & $\begin{array}{c}\text { Derajar } \\
\text { Bebas } \\
\text { Error }\end{array}$ & Sig \\
0,611 & 11,607 & 3 & 57 & 0,00 \\
\hline
\end{tabular}

Hipotesis Penelitian:

Ho: $\mathrm{F}_{\text {hitung }}=\mathrm{F}_{\text {tabel }}(3,15)$ dan $\mathrm{p} \geq \alpha=0,05$ Model TGT dan model Jigsaw dengan pendekatan saintifik pada pembelajaran ekonomi tidak ada perbedaan gain score kedua model tersebut.

Ha: $\mathrm{F}_{\text {hitung }}=\mathrm{F}_{\text {tabel }}(3,15)$ dan $\mathrm{p}<\alpha=0,05$ Model TGT dan model Jigsaw dengan pendekatan saintifik pada pembelajaran ekonomi ada perbedaan gain score kedua model tersebut.

Berdasarkan tabel tersebut tampak nilai $\mathrm{F}_{\text {hitung }}=11,607=\mathrm{F}$ tabel $=3,15$ dan siginifikansi diperoleh dari uji multivariat untuk membandingkan gain scoreranah kognitif, ranah afektif, dan ranah psikomotorik adalah $\mathrm{p}=0,000$ $<0,05$ yang menunjukkan bahwa Ho ditolak, dengan demikian ada perbedaan gain score hasil belajar ranah kognitif, ranah afektif, ranah psikomotorik siswa untuk materi yang diajarkan antara kelompok TGT dan kelompok Jigsaw.

Uji $t$ paried sample test membandingkan Gain Score dan indeks gain score dalam analisis lanjutan untuk mengetahui perbedaan lebih lanjut dua model TGT dan Jigsaw dengan 3 aspek yaitu aspek kognitif, afektif, dan psikomotorik.

Tabel 4. Komparasi Model TGT dan dengan uji t paried sample test Membandingkan Gain Score

\begin{tabular}{clccccc}
\hline No & $\begin{array}{c}\text { Hasil Belajar } \\
\text { Ranah }\end{array}$ & $\begin{array}{c}\text { Gain Score } \\
\text { TGT }\end{array}$ & $\begin{array}{c}\text { Gain Score } \\
\text { Jigsaw }\end{array}$ & Nilai F & T Hitung & Sig \\
\hline 1 & Kognitif & 25,69 & 15,04 & 0,669 & 4,069 & 0,000 \\
2 & Afektif & 4,69 & 8,52 & 1,826 & $-3,199$ & 0,002 \\
3 & Psikomotorik & 8,69 & 10,45 & 0,400 & 0,978 & 0,332 \\
\hline
\end{tabular}

Hipotesis Penelitian:

Ho: $\mathrm{t}_{\text {hitung }}=\mathrm{t}_{\text {tabel }}(2,04)$ dan $\mathrm{p} \geq \alpha=0,05$ kelompok eksperimen model TGT dengan pendekatan saintifik tidak memiliki perubahan yang signifikan dibanding dengan kelompok eksperimen model Jigsaw dengan pendekatan saintifik.
Ha: $\mathrm{t}_{\text {hitung }}=\mathrm{t}_{\text {tabel }}(2,04)$ dan $\mathrm{p}<\alpha=0,05$ kelompok eksperimen model TGT dengan pendekatan saintifik memiliki perubahan yang signifikan dibanding dengan kelompok eksperimen model Jigsaw dengan pendekatan saintifik. 
Tabel 5. Indeks Gain Score Model TGT dan Model Jigsaw.

\begin{tabular}{cccccc}
\hline No & Model & Kognitif & Afektif & Psikomotorik & Jumlah \\
\hline 1 & TGT & $60,49 \%$ & $22,94 \%$ & $36,48 \%$ & $120,91 \%$ \\
2 & Jigsaw & $45,80 \%$ & $39,33 \%$ & $45,44 \%$ & $130,57 \%$ \\
& & & & & \\
\hline
\end{tabular}

Hasil analisis Gain Score dengan Uji t terlihat perbedaan pada pada taraf 0,05 dan $\mathrm{t}_{\text {hitung }}$ $4,069=\mathrm{t}_{\text {tabel }} 2,04 ; \mathrm{p}: 0,182>0,05$ dan Indeks Gain pada TGT 60,49\% lebih besar dibandingkan dengan indeks gain model jigsaw 45,80\% yang berarti model TGT dengan pendekatan saintifik memilki perubahan yang signifikan hasil belajar ranah kognitif dibandingkan model Jigsaw dengan pendekatan saintifik. Hal ini diperkuat dengan sumbangan keefektifan (effect size) model TGT sebesar 20,32\% dibandingkan dengan model Jigaw.

Menurut Vygotsky, dalam pembelajaran siswa dibimbing oleh orang dewasa atau teman sebaya yang lebih kompeten untuk memahami sesuatu. Di dalam pembelajaran ekonomi dengan model TGT dan Jigsaw siswa lebih mudah memahami dengan berdiskusi dan bermain dengan teman dalam kelompok. Siswa berada dalam kelompok dapat bertanya kepada teman yang lebih kompeten sehingga siswa dapat saling membantu. Kegiatan yang aktif dalam kelompok membuat suasana tidak jenuh atau tegang dalam pembelajaran. Suasana tersebut dalam lebih mudah memahami materi yang sulit, membosankan lebih mudah diatasi adanya keterbukaan dengan teman lainnya.

Menurut teori kognitif bahwa kebebasan dan keterlibatan siswa secara aktif dalam proses belajar sangat diperlukan agar belajar lebih bermakna. Dalam model TGT dan Jigsaw siswa diberi kebebasan untuk membaca dari berbagai sumber aja seperti buku pelajaran dan internet sehingga siswa dipacu untuk aktif mempelajari materi secara mandiri. Berbagai macam aktivitas dan kegiatan yang dapat dilakukan siswa dalam proses pembelajaran membuat siswa lebih aktif untuk belajar. Tingginya tingkat aktivitas siswa di dalam pembelajaran ekonomi dengan model TGT dan Jigsaw dengan pendekatan saintifik menunjukkan bahwa keaktifan pembelajaran didominasi oleh siswa.

Hasil analisis Gain Score dengan uji t terlihat perbedaan pada pada taraf 0,05 dan $t$ hitung 3,199 =t tabel 2,04; p: $0,002<0,05$ dan Indeks Gain pada TGT 22,94\% lebih kecil dibandingkan dengan indeks gain model jigsaw $39,33 \%$ yang berarti model Jigsaw dengan pendekatan saintifik memilki perubahan yang signifikan hasil belajar afektik dibandingkan model TGT dengan pendekatan saintifik. Hal ini diperkuat dengan sumbangan keefektifan (effect size) model Jigsaw sebesar 13,15\% dibandingkan dengan model TGT.

Model pembelajaran TGT dan Jigsaw memotivasi siswa untuk kerjasama dalam kelompok. Kerjasama yang baik akan mudah dalam menerima dan memahami permasalahan yang ada. Permasalahan yang ada bisa diselesaikan melalui diskusi karena menerima banyak pendapatan atau pengetahuan yang baru sehingga mempermudah dalam menerima materi. Pada model TGT dan Jigsaw kebersamaan dimulai dari pengelompokan yang heterogen. Sikap menerima perbedaan sebagai langkah awal untuk kerjasama yang lebih kuat.

Hasil belajar ranah afektif dengan model TGT dan model Jigsaw bersifat positif didukung dengan hasil penelitian Slavin, R.E \& Karweit, N.L., (1981) tentang "Cognitif and affective outcomes of an intensive student team learning experience" menyimpulkan dalam penelitiannya bahwa penggunaan metode STAD, TGT, dan Jigsaw menghasilkan hasil yang posistif dalam persahabatan mahasiswa, keinginan sekolah, harga diri dan prestasi membaca siswa.

Model pembelajaran TGT dan Jigsaw siswa dibangun dengan ketika siswa diterima dalam kelompok, berani mengungkapkan, memperoleh perhatian atau penghargaan dari orang lain. Di dalam kelompok siswa berani mengungkapkan pendapat merupakan hal yang baik karena bisa mengomunikasi kepada orang lain sehingga dalam pendekatan saintifik langkah mengomunikasi terjadi terlihat dari hasil refleksi siswa.

Hasil komparasi Gain Score bahwa model TGT dengan pendekatan saintifik ada perbedaan 
keefektifan dengan perbandingan gain score lebih tinggi dibandingkan dengan dan model Jigsaw dengan pendekatan saintifik. Hasil pengamatan bahwa dengan model TGT dalam bermain dan berkompetisi bisa memunculkan sifat ego bagi siswa yang mempunyai kemampuan lebih tinggi sehingga kurang membantu teman lainnya. Hasil yang diperoleh dalam kompetisi tinggi tetapi didominasi oleh yang lebih pandai. Pada model Jigsaw bahwa masing-masing sebagai ahli dan kalau belum bisa mereka saling membantu sehingga kerjasamanya lebih baik. Mereka tidak berebut untuk memenangkan pertandingan melainkan saling membantu dan melengkapi.

Hasil analisis Gain Score dengan Uji $\mathrm{t}$ terlihat tidak ada perbedaan pada pada taraf 0,05 dan $\mathrm{t}$ hitung $0,978 \leq \mathrm{t}$ tabel 2,04; $\mathrm{p}$ : $0,332>0,05$ berarti model TGT dan model Jisaw dengan pendekatan saintifik tidak ada perbedaan keefektifan untuk hasil belajar ranah psikomotorik. Hal ini diperkuat dengan sumbangan keefektifan (effect size) model TGT sebesar $0,07 \%$ dibandingkan dengan model Jigsaw. Namun kalau dilihat dari indeks gain pada Jigsaw 45,44\% lebih besar dari indeks gain TGT 36,48\% sehingga bisa dikatakan Model Jigsaw ada perbedaan keefektifan dengan gain score lebih tinggi dibanding model TGT.

Dalam model TGT dan Jigsaw siswa diberi kebebasan untuk membaca dari berbagai sumber ajar seperti buku pelajaran dan internet sehingga siswa dipacu untuk aktif mempelajari materi secara mandiri. Model pembelajaran TGT dan Jigsaw siswa dibangun dengan ketika siswa diterima dalam kelompok, berani mengungkapkan, memperoleh perhatian atau penghargaan dari orang lain. Hasil belajar ranah psikomotorik hasilnya sama efektinya dengan model TGT dan dengan model Jigsaw. Hasil penelitian ini didukung oleh penelitian dari : (1) Persky \& Pollack, GM. (2009) tentang "Hybrig Jigsaw to Teaching Renal Clearence Cocsept:" menjelaskan bahwa hasil belajar siswa tidak ada perbedaan dalam kinerja antara model TGT dibandingkan model Jigsaw. (2) Hasil penelitian Sare Sengul \& Yasemin Katranci. (2014) tentang "Effects of jigsaw technique on mathematics selfefficacy perceptions of seventh grade primary school students" menjelaskan bahwa tidak ada perbedaan yang signifikan antara skor pretest dengan posttest siswa tetapi teknik jigsaw memiliki efek persepsi siswa yang maju pada matematika.

Pendekatan saintifik sangat membantu dalam memahami karena siswa diajak langsung terlibat dalam pembelajaran secara kronologis atau secara ilmiah. Siswa melihat sesuatu, bertanya hal-hal yang kurang jelas atau kurang dimengerti, bertanya kepada teman dalam kelompok atau kepada guru. Komunikasi dua arah tercipta interaksi antarsiswa, siswa mau mendengarkan, menjelaskan terlihat dalam diskusi model TGT maupun model Jigsaw. Belajar secara sistimetis memudahkan siswa memahami ilmu pengetahuan.

Berdasarkan perhitungan analisis gain score model TGT diperoleh indeks gain hasil belajar ranah kognitif $=60,49 \%$, indeks gain hasil belajar ranah afektif $=22,94 \%$, dan indeks gain hasil belajar ranah psikomotorik 36,48\% sehingga apabila dijumlahkan 120,91\% sedangkan untuk model Jigsaw diperoleh indeks gain hasil belajar ranah kognitif $=45,80 \%$, indeks gain hasil belajar ranah afektif $=39,94 \%$, dan indeks gain hasil belajar ranah psikomotorik $45,44 \%$ sehingga apabila dijumlahkan 130,57\% . Jumlah indeks gain ranah kognitif, ranah afektif, ranah psikomotorik model TGT $=120,91 \%$ lebih kecil dibandingkan dengan jumlah indeks gain ranah kognitif, ranah afektif, ranah psikomotorik model Jigsaw $=130,57 \%$ sehingga bisa dikatakan model Jigsaw ada perbedaan keefektifan dibandingkan model TGT.

\section{Simpulan dan Saran}

Simpulan

Hasil analisis dan pembahasan yang telah dilakukan, maka dapat disimpulkan sebagai berikut:1) Model pembelajaran Teams Games Tournamentdan model Jigsaw dengan pendekatan saintifik efektif meningkatkan kemampuan ranah kognitif, ranah afektif dan ranah psikomotorik. (2) Ada perbedaan keefektifan pembelajaran Teams Games Tournament (TGT) dengan model Jigsaw dengan pendekatan saintifik dalam pembelajaran ekonomi SMA Negeri di Kabupaten Sleman. (a) Perbedaan keefektifan model TGT dibandingkan model Jigsaw dibuktikan dengan analisis Gain Score pada model TGT 60,49\% lebih tinggi besar dibandingkan indeks gain model Jigsaw $45,80 \%$, sumbangan keefektifan model TGT $19,14 \%$ dibandingkan dengan model Jigsaw. 
(b) Perbedaan keefektifan dibandingkan model TGT dibuktikan dengan analisis Gain Score pada model Jigsaw 39,33\% lebih besar dibandingkan indeks gain model TGT 22,94\%, sumbangan keefektifan model jigsaw 13,15\% dibandingkan dengan model TGT.(c) Tidak ada perbedaan kefektifan model TGT dan model Jigsaw dibuktikan dengan sumbangan keefektifan model Jigsaw $0,07 \%$ dibandingkan dengan model TGT walaupun indeks gain pada model Jisaw $45,44 \%$ lebih besar dari indeks gain model TGT 36,48\%.

Implikasi

Penelitian ini merupakan penelitian eksperimen yang berusaha mengambarkan pengaruh model Teams Games Tournament dan Jigsaw dalam pembelajaran ekonomi SMA Negeri di Kabupaten Sleman. Berdasarkan kesimpulan, penelitian ini menunjukkan implikasi sebagai berikut: (1) Secara teori model Teams Games Tournament dan Jigsaw dengan pendekatan saintifik menjadi alternatif model pembalajaran yang dapat digunakan untuk meningkatkan kompetensi ranah kognitif, ranah afektif, dan ranah psikomotorik dalam pembelajaran ekonomi. (2) Model pembelajaran Team Games Tournament menumbuhkan persaingan sehat antara kelompok yang satu dengan yang lain menjadikan suasana gembira atau suasana tidak tegang sehingga akan meningkatkan motivasi dan ketertarikan mengikuti pelajaran. (3) Model pembelajaran jigsaw menumbuhkan suasana untuk menguasai bahan karena merasa malu kalau tidak bisa menjelaskan kepada teman dalam kelompok sehingga termotivasi untuk menguasai materi. Siswa lebih percaya diri dengan materi yang telah dipahami untuk menjelaskan kepada teman lannya. (4) Hasil penelitian menunjukkan bahwa model pembelajaran Teams Games Tournament dan Jigsaw dengan pendekatan saintifik dalam pembelajaran ekonomi SMA mampu meningkatkan kemampuan ranah kognitif, kemampuan ranah afektif, dan kemampuan ranah psikomotorik.

Saran

Berdasarkan hasil temuan penelitian dan memperhatikan keterbatasan penelitian, saran yang dapat disampaikan sebagai berikut: (1) Disarankan kepada guru agar kedua model pembelajaran Teams Games Tournament dan Jigsaw dengan pendekatan saintifik dapat digunakan oleh para guru dalam pembelajaran ekonomi karena dari hasil refleksi siswa merasa senang, berminat, dan bermanfaat dalam mengikuti pembelajaran dengan model tersebut. (2) Disarakan kepada kepala sekolah agar merekomenasikan kepada guru terutama guru ekonomi untuk menggunakan model pembelajaran Teams Games Tournament dan Jigsaw dengan pendekatan saintifik. (3) Disarankan kepada peneliti lain untuk mengkaji penerapkan model pembelajaran Team Games Tournament dan Jigsaw dengan pendekatan saintifik dapat diteliti lebih lanjut dengan materi dan variabel dependen yang lain.

\section{Daftar Pustaka}

Adams, F.H. (2013). Using jigsaw technique an effective way of promoting cooperative learning among primary six pupils in Fijai. International Journal of Education and Practice, 1 (6): 64-74.

Arsaythamby, V.\& Sitie, C. (2013). Fostering students attitudes and achievemengt in probalility using teams games tournament. Procedia Sosial and Behavioral Science (93). 59-64.

Diklat Guru Implementasi kurikulum 2013. (2013). Mata diklat: 2 analisis materi ajar jenjang SD/SMP/SMA mata pelajaran: konsep pendekatan saintifik. Kementerian Pendidikan dan kebudayaan.

Emzir. (2013). Metodologi penelitian pendidikan kuantitatif \& kualitatif. Jakarta: PT. Rajawali Press.

Ke, Fengfeng \& Grabowski, Barbara. (2007). Gameplaying for maths Learning: Cooperative or not?. British Journal of Educational Technology. 38 (2): 149-259.

Gonzales, A., Jennings, D, \& Manriquez, L. (2014). Multi-faceted impact of a team games tournament on the ability of the learners to engage and develop their own critical skill set. International Journal of Engineering Education, 30 (5): 12131224.

Kedaulatan Rakyat. (23 November 2014). Implementasi kurikulum 2013 Guru sebagai subjek perubahan. hal 2.

Johnson, D.W., Johnson, R.T., \& Stanne. M.B. (2000). Cooperative learning methods: a 
meta-analysis. Minnesota: Univercity of Minnesota.

Kartikawati, C. E. (2012). Peningkatan aktifitas dan prestasi belajar menyusun laporan keuangan melalui metode pembelajaran kooperatif model Jigsaw bagi siswa kelas X akuntansi 3 SMK N 4 Klaten semester genap tahun 2012. Jurnal pendidikan Ekonomi \& Akuntansi USD. 6 (1): 1-20.

Kemendikbud. (2013). Diklat guru implementasi kurikulum 2013: materi pelajaran konsep pendekatan scientific. Jakarta.

Persky, A.M., \& Pollack, G.M. (2009). A hybrid jigsaw approach to teaching renal clearence cocepts. American Journal of Pharmaceutical Education. Univercity of North California at Chapel Hill. 73 (3): 49.

Kedaulatan Rakyat. (19 November 2014). Perbaikan metode mengajar jadi keharusan. hal 10.

Kedaulatan Rakyat. (27 November 2014). Perbaikan metode jadi keharusan masih banyak Guru yang tidak kreatif. hal 10.

Mengduo, Qiao \& Xiaoling, Jin. (2010). Jigsaw strategy as cooperative learning technique: focusing on the language learners. Chinese Journal of Applied Liguistics (Bimonthly). 33 (4).
Rusman (2013). Model-model pembelajaran: mengembangkan profesionalisme guru. Jakarta: PT. Raja Grafindo Persada.

Saptono, L. (2011). Implemantasi model team games tournament sebagai upaya meningktakan prestasi belajar siswa dalam pembelajaran ekonomi. Jurnal pendidikan Ekonomi \& Akuntansi USD. 4 (2), 35-45.

Senggul, Sare \& Katranci,Yasemin. (2014). Effects of jigsaw technique on mathematics self-efficacyperceptions of seventh grade primary school students. Procedia and Behavior Science.116, 333-338.

Senggul, Sare \& Katranci,Yasemin.(2014). Effects of jigsaw technique on seventh grade primary school students attitute towards matematics. Procedia and Behavior Science.116, 339-344.

Slavin, R.E. \& Karweit, N.L. (1981). Cognitif and affective outcomes of an intensive student team learning experience. The Journal ofExperiemental Education, Vol 50, Issu 1, 29-35.

Sugiyono. (2014). Metode penelitian kuantitatif, kualitatif dan $R \& D$. Bandung: Alfabeta.

Wiersma, W. (1995) Research methods in education. $6^{\text {th }}$ edition, Needham Heights, Massachusetts: Allyn and Bacon, A Simon and Schuster Company. 